\title{
Integration of Quality Function Deployment and Value Engineering: A Case Study On Waiting Chair Products
}

\author{
Imam Safi' ${ }^{1}{ }^{*}$, Silvi Rushanti Widodo ${ }^{1}$, Dyah Lintang Trenggonowati ${ }^{2}$ \\ ${ }^{1}$ Industrial Engineering Department, Faculty of Engineering, Universitas Kadiri, Kediri, Indonesia, \\ ${ }^{2}$ Industrial Engineering Department, Faculty of Engineering, Universitas Sultan Ageng Tirtayasa, Banten, \\ Indonesia \\ *Corresponding author: imam@ unik-kediri.ac.id
}

\begin{abstract}
The purpose of this research is to determine a better alternative to the development of waiting chair products by using the integration of QFD method and value engineering so that the product obtained by the appropriate and to reduce production costs without eliminate the product functions. 40 respondents taken in incidental sampling techniques and provides data through the transfer of the questionnaire to obtain the attributes of the consumer's need for a waiting chair product while 5 teams from the manufacturer accommodate through the attributes of technical needs with House of Quality to get priority product technical improvement. Value Engineering aims at finding alternatives and identifying product concepts that have greater value. The result of this research show that the integration of Quality Function Deployment and Value Engineering can identify the priority of product improvement based on customer's needs and decrease the cost of making the product with the highest ratio value is in the alternative II of 0.00634 . If viewed from the cost of making the initial product is IDR 546.500,00 then after the stage of this research, the cost of making decrease of IDR 90.625,00.
\end{abstract}

Key words : Quality function, House of quality, Value engineering, QFD

\section{INTRODUCTION}

Industrial Engineering at the Kadiri University Faculty of Engineering has conceptualized the waiting chair product at the previous drawing engineering practicum in 2017. According to the results of a questionnaire distributed to 40 respondents, stated that the existing seat model is less comfortable (can cause back pain to the pelvis and so on) and when tidied takes up a lot of places. Then the physical prototype is continued in the manufacturing process in 2018. From the waiting chair product concept, we need to do research that has the aim to develop a product concept design that meets customer demand appraisal and low production costs. According to [1] product development aims to develop existing products, so that customer satisfaction will increase and even be met as a whole.

Economic success most companies depend on their ability to identify customer needs and full their needs so it can be manufactured at low cost [2]. Quality Function Deployment is one of method that use for development product and increase the quality of product. Quality Function Deployment is a product development and quality management methodology that was first introduced in Japan as a quality enhancement tool. Product development and quality improvement are based on the principle of customer demand [3]. QFD methods are used in developing products upon request from customers [4]. The overall concept of QFD provides a means of translating customer requirements to the technical requirements for each stage of product development and production [5].

Products made with regard to overall quality will incur high production costs, therefore many companies that want to reduce costs in production by not eliminating the functions of the product [6]. Value engineering is a system used to create a design by establishing a clear purpose and expanding it as desired [7]. SAVE (Society Of American Value Engineering) mentions that value engineering as a technique to develop product functions in a low cost [8].

Submitting a new product successfully to the market is the result of a well-defined new product development process [9], which includes planning, concept development, system level design, detailed design, testing and debugging, and trial production phases [10]. The new product development process begins with the planning stage [11]. The outputs of this phase constitute the introduction of the concept development phase at the same time, and these inputs lead to the new product development team. The final stage of the new product development process is to present the product to the market and make the product ready for purchase [12].

The integration concept of QFD and value engineering methods has been conducted by [4] by adding the Design for Manufacture and Assembly (DFMA) method to the design 
Imam Safi'i et al., International Journal of Emerging Trends in Engineering Research, 8(7), July 2020, 4819 - 4827

process of a product [13]. Where the integration between QFD and value engineering has the main objective to choose a better alternative in product/service planning or process products/services that not only produce higher value for customers, but also not increase the cost of products/services. More detail can seen in Figure 1 about releationship between QFD and Value Engineering [4].

\section{METHODOLOGY}

The product planning process based on QFD principle starts by taking into customer needs and requirements. Product characteristics associated with this requirement are determined. Solutions (alternatives) contribute to the fulfillment of these needs identified. Then use the value engineering technique as a solution that has a higher value index for the selected customer. Integration Conceptual QFD Model \& Value Engineering can be seen in Figure 1.

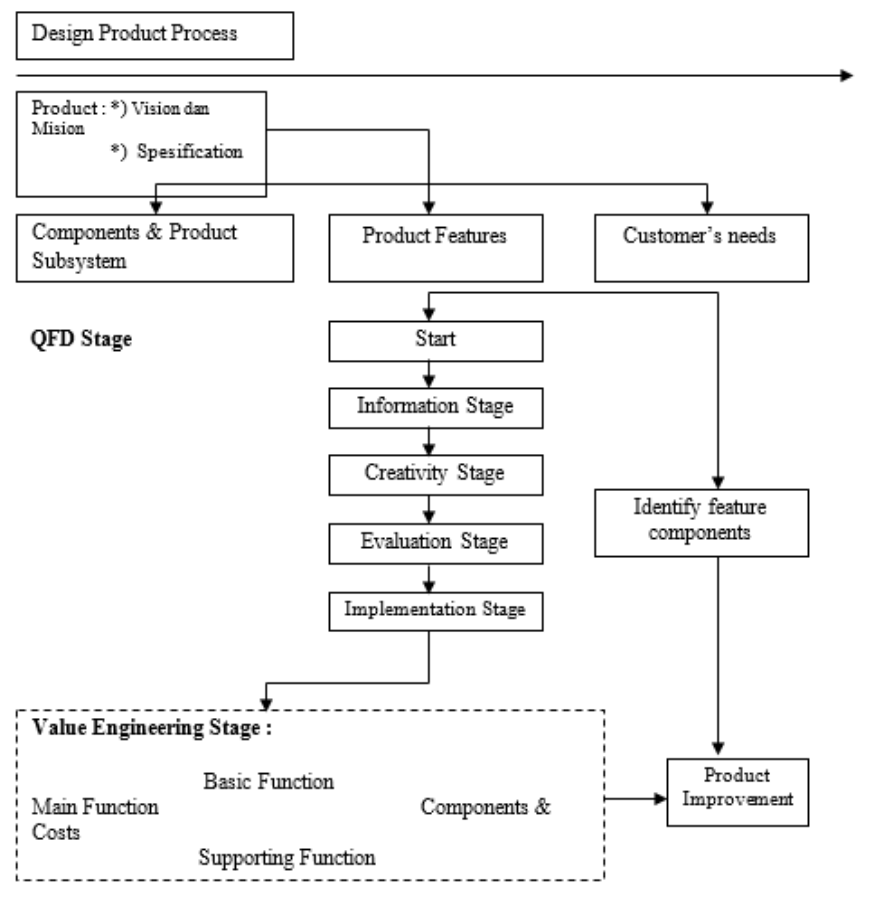

Figure 1: Integration conceptual QFD model \& value engineering

This research is product development because the process identifies improved product attributes better. Development research as a systematic assessment of the study, development, and evaluation of programs, processes and learning products that must meet the criteria for validity, practicality, and effectiveness [14]. The research did in the Laboratory of Industrial Engineering major of Kadiri University with waiting chair products.

Customer requirements are changing very quickly [15]. Thus, it is very important for firms to be able to respond to customer requirements quickly and accurately so that they can take more shares in the market [16]. At the first stage of the design process, customer requirements should be determined and a list of product specifications should be developed based on these customer requirements. These specifications must be ensured by the product. The next stage of concept design is the design process and involves the establishment of subsystems. Once the various concepts are identified, the best combination of the sub-sets with the highest performance and lowest cost is selected. This process is called concept selection [17]. After this phase, the design process progresses towards a detailed resolution. The goal of the concept selection, which is one of the stages of the concept development process, is to choose the most appropriate one at the beginning of the process [18]. So, the purpose of this research is to determine a better alternative to the developed waiting chair products using the integration of QFD and value engineering methods.

An open questionnaire is given to 40 customers who use the waiting chair who already represent from the waiting chair user. Question on the open questionnaire is when and why do you use this waiting chair? what is the advantage of the waiting chair you are currently using? What is the lack of a waiting chair that you use today? What are some things you consider when buying a waiting chair? What improvements do you want to have on your existing waiting chair?

On the closed questionnaire the data collection can be said to be the most effective because the respondents can directly provide answers with a checklist $(\sqrt{ })$ in the column that has been provided. There are several stages in a closed questionnaire, such as:

1. Enter the attribute of the need statement derived from the open questionnaire as a query in the closed questionnaire [19].

2. Spreading the questionnaire closed to the respondent [20].

3. Analyzes data tabulation from closed questionnaire [21].

A closed questionnaire question was given to customer who used a waiting chair of 40 respondents who already represented a multifunctional waiting chair user with incidental sampling techniques. Closed questionnaire to know the level of importance of each attribute. The range assessments on the questionnaire are closed as follows $(1=$ very not important $),(2=$ not important $),(3=$ pretty Important), (4 = Important), (5 = very important $)$.

The value of relationship in relationship matrix is determined by the observation and also the interview of the manufacturer. How to fill this matrix by determining the appropriate impact between the relationship needs of techniques and customer needs.

On the increase of the technical interest is divided into two parts, first is value of absolute importance and second is value 
Imam Safi'i et al., International Journal of Emerging Trends in Engineering Research, 8(7), July 2020,4819 - 4827

of the relative importance. This value shows which activities need to first take precedence among other activities. The value of absolute interest is obtained by the way of the customer interest that has a relationship with the attribute of technical needs with the value of the relationship of customer expectation with the attributes of existing technical needs with the formula as:

$$
A T=\sum(B t i H i)
$$

Explanation :

AI : The absolute significance value for each attribute Bti : Weight of the desires of consumers who have relationships with the attributes of technical needs.

$\mathrm{Hi}$ : The value of the relationship of consumer desires by attributable to existing technical needs.

To find the value of relative interest gained by calculating using the way each value of absolute interest multiplied by one hundred percent $(100 \%)$ with the formula as follows :

$$
\mathrm{RI}=\left[\left(\mathrm{Kti} / \sum \mathrm{Kti}\right) \times 100 \%\right]
$$

Explanation :

Kti : Value of the absolute importance of technical needs

$\Sigma \mathrm{kti}$ : Total of absolute value interest from technical need

Some examples of product development process can be found in [22] and [23]/

\section{RESULT AND DISCUSSION}

In this study requires really reliable and valid data, then in this case the questionnaire will be tested first before being used as a primary data in the research. All of the above tests are done in order to obtain evidence of how far the precision and accuracy of the measuring instrument is in performing its measuring function. In this testing variable 7 attributes adapted from the customer needs attributes include comfortable, there is backup, strong material, appropriate body size, easy to use, multifunctional, and reasonably priced.

Table 1: Customer needs and technical needs

\begin{tabular}{|c|l|c|c|}
\hline No & Customer Needs & $\begin{array}{c}\text { Average } \\
\text { Customer } \\
\text { Expectations }\end{array}$ & Technical Needs \\
\hline 1 & Comfortable & 4.67 & $\begin{array}{c}\text { Comfortable } \\
\text { seating mat }\end{array}$ \\
\hline 2 & $\begin{array}{l}\text { Reasonably } \\
\text { priced }\end{array}$ & 4.30 & Competitive price \\
\hline 3 & Multifunction & 4.00 & $\begin{array}{c}\text { Other functions } \\
\text { besides waiting } \\
\text { chairs }\end{array}$ \\
\hline 4 & There is backup & 3.93 & Additional facilities \\
\hline 5 & Easy to use & 3.67 & Assembling \\
\hline 6 & Ergonomic & 3.63 & $\begin{array}{c}\text { Appropriate body } \\
\text { size }\end{array}$ \\
\hline 7 & Strong material & 3.33 & Material quality \\
\hline
\end{tabular}

The result of the validity test with a factor analysis indicates a KMO value of 0.584 from the result indicating that the instrument is valid because it already meets the $0.50(0.584>$ $0.50)$ limit. The anti-image correlation results in a correlation greater than 0.50 for each attribute, i.e. $0.530(\mathrm{X} 1) ; 0.638$ (X2); 0.666 (X3); 0.576 (X4); 0.566 (X5); 0.604 (X6); 0.619 (X7). Based on the correlation result is high enough, that can be expressed 7 attributes can be used to measure the contraction of the product-forming criteria. While Cronbach's Alpha value in the results of reliability test $=0.669$ with a number of items $=7$ items, then on the reusability of Cronbach's Alpha test $>$ The minimum value of Cronbach's. Minimal Cronbach 0.6.

\subsection{QFD Phase}

In making the product design matrix, the most important step is to translate the customer needs into technical needs, this aims to explain the specifications in general the design will be developed. Technical needs data is obtained by interview methods to 5 teams of waiting chair products that accommodate the customer needs. As for the techniques needs that customers expect based on each voice of customer can be seen in the Table 1 .

This section shows the direction of improvement to any existing technical needs can be seen in Table 2 .

\begin{tabular}{|c|c|c|}
\hline No & Technical Needs & Target \\
\hline 1 & $\begin{array}{l}\text { Comfortable seating } \\
\text { mat }\end{array}$ & Add sponge in seats \\
\hline 2 & Additional facilities & There is backup \\
\hline 3 & Material quality & Using iron. \\
\hline 4 & Appropriate body size & $\begin{array}{l}\text { Adjust the average body size of } \\
\text { Indonesian anthropometry. }\end{array}$ \\
\hline 5 & Easy to assembly & $\begin{array}{l}\text { Adjust the sitting position only } \\
\text { or with the table at once. }\end{array}$ \\
\hline 6 & $\begin{array}{l}\text { Other functions besides } \\
\text { waiting chairs }\end{array}$ & Can be used as chair, and table. \\
\hline 7 & Competitive price & Not more than IDR 500,000 \\
\hline
\end{tabular}

Table 2: Target technical needs

The correlation matrix is a triangle-shaped image resembling a house roof, and the matrix is usually combined with the technical needs. Usually this correlation of matrix is at the very top of the QFD matrix can be seen in Figure 2.

Following an example of the calculation of absolute importance on the technical needs of pricing, absolute interest is calculated in the following: $\mathrm{AI}=(3,93 \times 3)+(3,33 \times 9)+(4$ x 3$)+(4,30 \times 9)=92,4$. Calculating the value of absolute interest is done on all technical needs. 


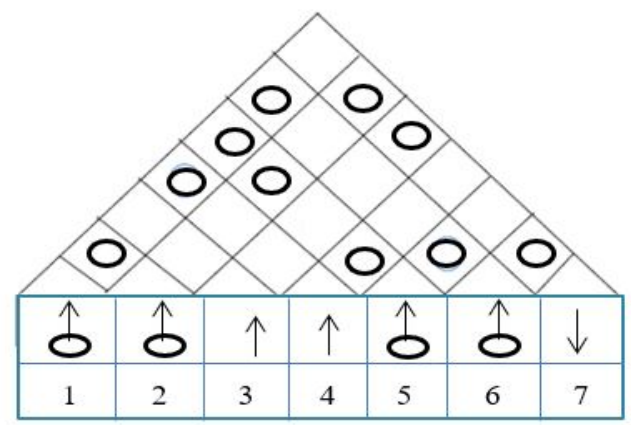

Figure 2: Correlation between technical needs
Following the calculation of relative importance on the technical needs of pricing, relative interest is calculated in the following: $\Sigma \mathrm{kt} i=84,6+32,9+68,6+86,6+103,1+63,7+92,4=$ 532,24 . Then the value of relative importance $(\mathrm{RI})=$ $92,4 / 532,24 \times 100 \%=17,3$.Likewise, by calculating the needs of other techniques, this is done in the same way until all is completed. Relation Matrix, absolute importance, and relative importance can be seen in Table 3 .

Table 3: Relation matrix, absolute importance and relative importance

\begin{tabular}{|c|c|c|c|c|c|c|c|c|c|}
\hline \multirow{2}{*}{ Customer needs } & \multirow{2}{*}{ IR } & \multicolumn{7}{|c|}{ Technical needs } & \multirow[b]{9}{*}{ Total } \\
\hline & & 1 & 2 & 3 & 4 & 5 & 6 & 7 & \\
\hline Comfortable & 4,67 & 9 & 1 & & 9 & 3 & & & \\
\hline There is backup & 3,93 & 1 & 3 & & 1 & 1 & 1 & 3 & \\
\hline Strong material & 3,33 & & & 9 & & & & 9 & \\
\hline Ergonomic & 3,67 & 3 & & & 9 & 1 & & & \\
\hline Easy to use & 3,63 & 3 & 1 & & 1 & 9 & 3 & & \\
\hline Multifunction & 4,00 & 3 & & & 1 & 9 & 9 & 3 & \\
\hline Reasonably price & 4,30 & 1 & 3 & 9 & & 3 & 3 & 9 & \\
\hline \multicolumn{2}{|c|}{ Absolute Importance } & 84.6 & 32.9 & 68.6 & 86.6 & 103.1 & 63.7 & 92.4 & 532.24 \\
\hline \multicolumn{2}{|c|}{ Relative Importance } & 15.8 & 6.19 & 12.9 & 16.2 & 19.3 & 11.9 & 17.3 & 100 \\
\hline
\end{tabular}

Value of absolute interests technical needs comfortable seating 84.6 , additional facilities 32.9 , material quality 68.6 , ergonomic 86.6, easy in assembling 103.1, other functions besides the waiting seat 63.7 , competitive price 92.4 . While the value of the relative importance of technical needs is the comfortable seat mat 15.8, additional facilities 6.19, material quality 12.9 , ergonomic 16.2 , easy to assemble 19.3 , function besides waiting chair 11.9 competitive price 17.3. The biggest value on the relative importance of technical needs is prioritized for consideration of product development i.e. easy-to-assemble attributes.

\subsection{Phase Value Engineering}

At this information stage focused on the value of the relative importance of product technical needs at the QFD stage. The results of interviews with the manufacturer of product manufacturers describe the waiting seat products that are based on hollow pipes and wooden planks. The base material used is $2 \times 2$ pipe size and $3 \times 3$ full pipe, with a seat height of $450 \mathrm{~mm}$, width of $380 \mathrm{~mm}$, length $2,000 \mathrm{~mm}$. While the table height is $790 \mathrm{~mm}$, width $300 \mathrm{~mm}$, length 2,000 mm. Seating area and desk are fitted with wooden planks. In addition, there is information that the cost of making a waiting chair product according to specification above is IDR 546.500,00 Here's the picture that shows the production of waiting chair products from industrial Engineering of Kadiri University. Figure 3 shows from dise view and Figure 4 shows from back view.
FAST (Function Analysis System Technique) is a way of mapping functions and techniques of solving problems by way of identifying functions. This is FAST diagram of waiting chair product can be seen in Figure 5.

From the results of the analysis on the figure 5, it shows that in making creative stage is more pressed on the product dimensions to accommodate from the value of the importance of the relative technical needs of the product.

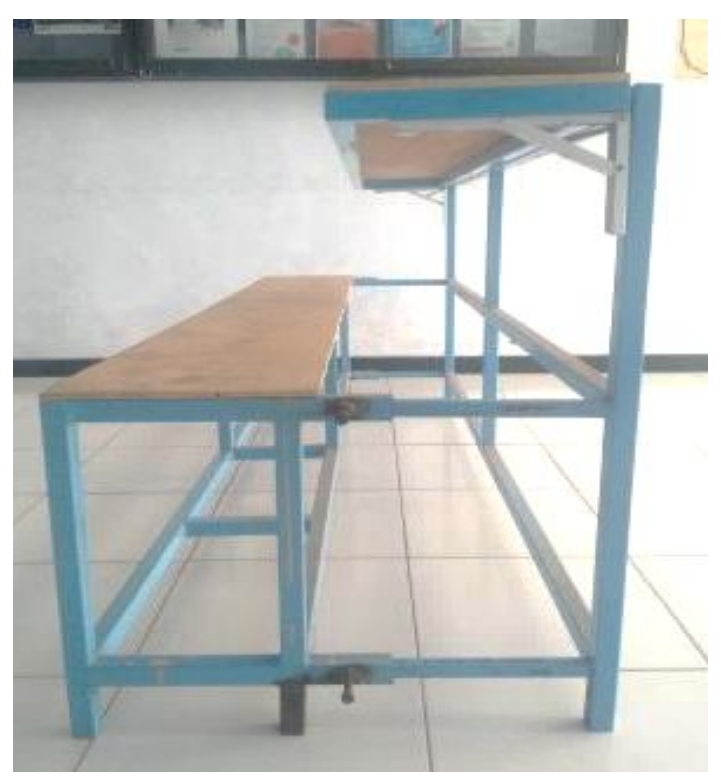

Figure 3: Side view 
Imam Safi'i et al., International Journal of Emerging Trends in Engineering Research, 8(7), July 2020, 4819 - 4827

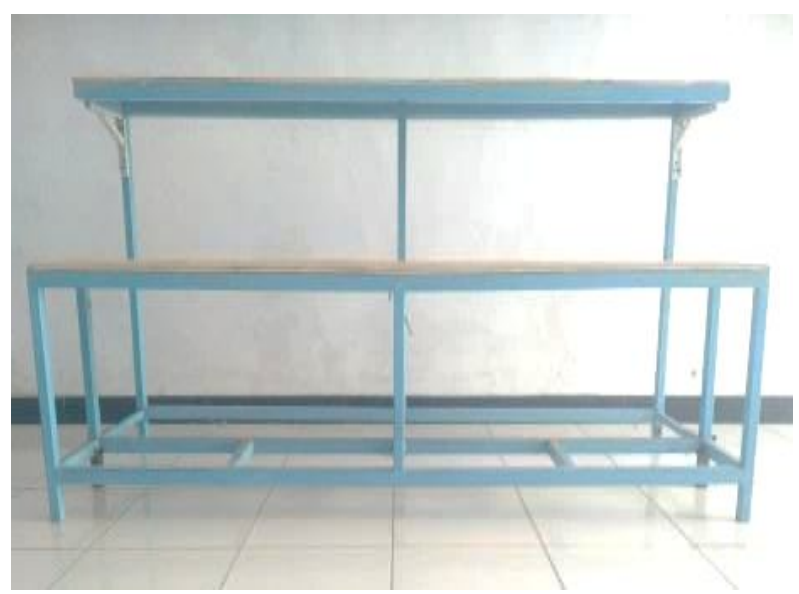

Figure 4: Back view

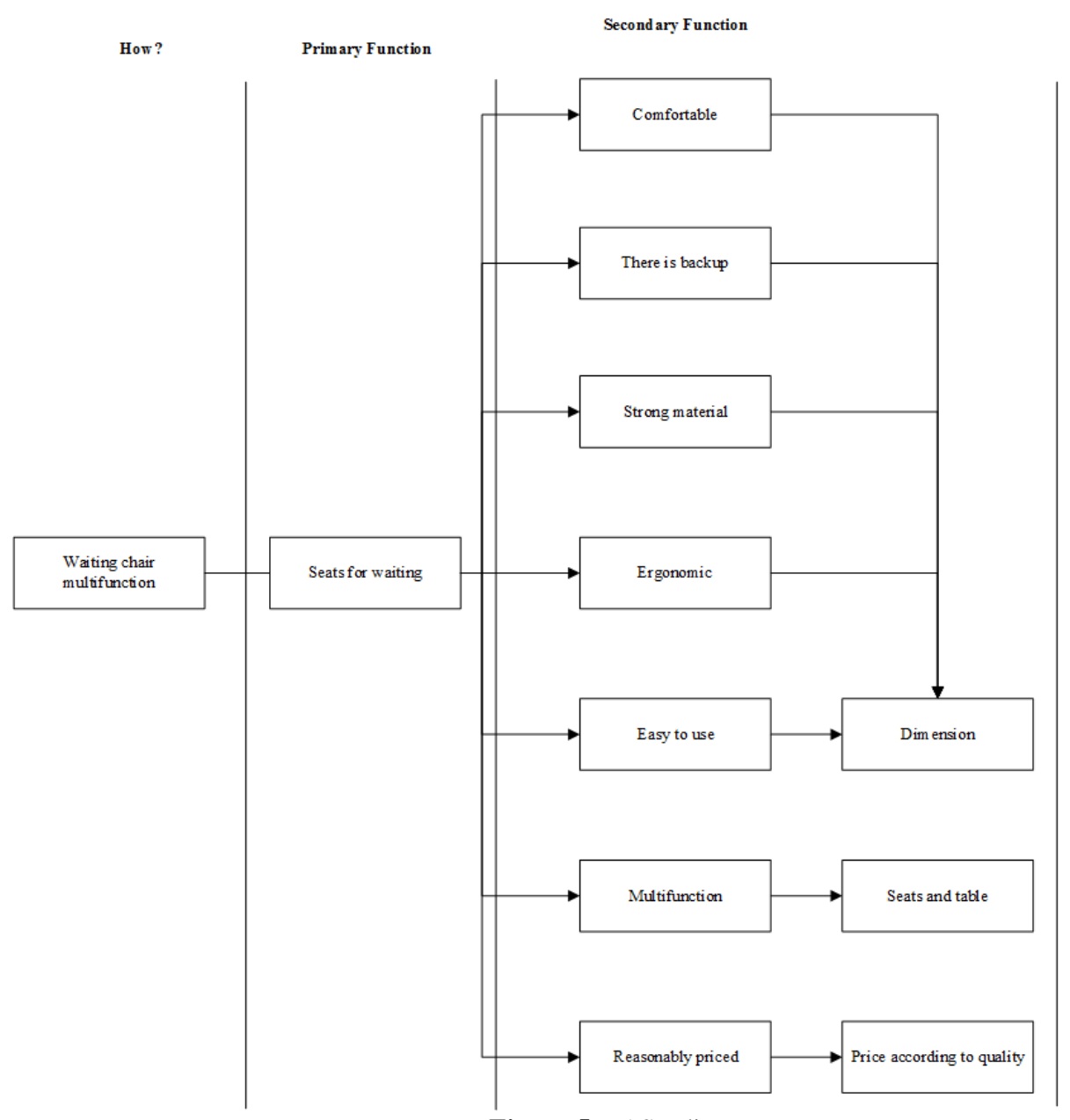

Figure 5. FAST diagram 
Imam Safi'i et al., International Journal of Emerging Trends in Engineering Research, 8(7), July 2020, 4819 - 4827

Table 4: An alternative to multifunctional chair design

\begin{tabular}{|l|l|l|l|}
\hline \multicolumn{1}{|c|}{ Product Spesification } & \multicolumn{1}{|c|}{ Alternative I } & \multicolumn{1}{c|}{ Alternative II } & \multicolumn{1}{c|}{ Alternative III } \\
\hline $\begin{array}{l}\text { Basic size under table } \\
\text { and chair }\end{array}$ & $\begin{array}{l}\text { Length }=1990 \mathrm{~mm} \\
\text { Width }=430 \mathrm{~mm}\end{array}$ & $\begin{array}{l}\text { Length }=1800 \mathrm{~mm} \\
\text { Width }=350 \mathrm{~mm}\end{array}$ & $\begin{array}{l}\text { Length }=2000 \mathrm{~mm} \\
\text { Width }=350 \mathrm{~mm}\end{array}$ \\
\hline Seat size & $\begin{array}{l}\text { Length }=1990 \mathrm{~mm} \\
\text { Width }=383 \mathrm{~mm}\end{array}$ & $\begin{array}{l}\text { Length }=1800 \mathrm{~mm} \\
\text { Width }=350 \mathrm{~mm} \\
\text { Height }=400 \mathrm{~mm}\end{array}$ & $\begin{array}{l}\text { Length }=2000 \mathrm{~mm} \\
\text { Width }=350 \mathrm{~mm} \\
\text { Height }=410 \mathrm{~mm}\end{array}$ \\
\hline Table size & $\begin{array}{l}\text { Length }=1990 \mathrm{~mm} \\
\text { Width }=300 \mathrm{~mm} \\
\text { Height }=725 \mathrm{~mm}\end{array}$ & $\begin{array}{l}\text { Length }=1800 \mathrm{~mm} \\
\text { Width }=400 \mathrm{~mm} \\
\text { Height }=700 \mathrm{~mm}\end{array}$ & $\begin{array}{l}\text { Length }=2000 \mathrm{~mm} \\
\text { Width }=300 \mathrm{~mm} \\
\text { Height }=660 \mathrm{~mm}\end{array}$ \\
\hline Lock of table and chair & - & Iron Elbow Locking & Locking Metals \\
\hline Main material & Iron & Iron & Iron \\
\hline Seat material & $\begin{array}{l}\text { Wood plank with the } \\
\text { thickness } 20 \mathrm{~mm}\end{array}$ & $\begin{array}{l}\text { Wood plank with the } \\
\text { thickness } 20 \mathrm{~mm} \text { and } \\
\text { covered with sponge }\end{array}$ & $\begin{array}{l}\text { Wood plank with the } \\
\text { thickness 20mm and } \\
\text { covered with sponge }\end{array}$ \\
\hline Table mat & $\begin{array}{l}\text { Wood plank with the } \\
\text { thickness } 20 \mathrm{~mm}\end{array}$ & $\begin{array}{l}\text { Wood plank with the } \\
\text { thickness 20mm and } \\
\text { removable sponge }\end{array}$ & $\begin{array}{l}\text { Wood plank with the } \\
\text { thickness 20mm }\end{array}$ \\
\hline $\begin{array}{l}\text { As multifunction waiting } \\
\text { chair }\end{array}$ & $\begin{array}{l}\text { Waiting chair can } \\
\text { have a function to be a } \\
\text { table }\end{array}$ & $\begin{array}{l}\text { Waiting chair can have a a } \\
\text { function to be a table }\end{array}$ & $\begin{array}{l}\text { Waiting chair can have } \\
\text { a function to be a table }\end{array}$ \\
\hline
\end{tabular}


Imam Safi'i et al., International Journal of Emerging Trends in Engineering Research, 8(7), July 2020, 4819 - 4827

At this creative stage is analyzing the same functions to meet other alternative uses. Based on the level of information criteria customer needs waiting chair product is developed alternative products according to the results of the level of information visible on the table 4 . At this stage is analyzing the same functions to meet the usability of other alternatives. Based on the information criteria of the customer needs of the waiting chair product is made basic consideration to develop the waiting chair design. The criteria of customer needs is in the function of the waiting chair itself. For alternatives can be seen from the following table.

To make weighted criteria, the analysis of the product formation of waiting seats to the proposed alternatives according to their respective criteria. The data presented is the data in the assessment of the 5 panelists that includes users and producers to each proposed alternative by delivering a value range of $0-100$ per product requirement criteria. The results of the performance analysis can be seen in table 5 .

Table 5: Alternative performance

\begin{tabular}{|l|c|c|c|}
\hline \multirow{2}{*}{ Need's criteria } & \multicolumn{3}{|c|}{ Alternative } \\
\cline { 2 - 4 } & 1 & 2 & 3 \\
\cline { 2 - 4 } & Weight & Weight & Weight \\
\hline Comfortable & 380 & 390 & 407 \\
\hline There is backup & 395 & 390 & 385 \\
\hline Iron material & 405 & 385 & 410 \\
\hline Ergonomic & 365 & 377 & 383 \\
\hline Easy to use & 391 & 402 & 392 \\
\hline Multifunction & 408 & 398 & 395 \\
\hline Reasonably priced & 383 & 382 & 390 \\
\hline $\begin{array}{l}\text { Total of product } \\
\text { performance }\end{array}$ & 2727 & 2724 & 2762 \\
\hline
\end{tabular}

Table 6: Calculation of alternative I

\begin{tabular}{|l|l|c|c|c|c|}
\hline No & Material & Diameter & $\begin{array}{c}\text { Unit } \\
\text { Price }\end{array}$ & Amount & Total \\
\hline 1. & $\begin{array}{l}\text { Hollow } \\
\text { Iron 3x3 }\end{array}$ & $1.2 \mathrm{~mm}$ & $\begin{array}{c}\text { IDR } \\
66,000\end{array}$ & 3.5 & $\begin{array}{c}\text { IDR } \\
231,000\end{array}$ \\
\hline 2. & $\begin{array}{l}\text { Wooden } \\
\text { Planks }\end{array}$ & & $\begin{array}{c}\text { IDR } \\
70,000\end{array}$ & 1 & $\begin{array}{c}\text { Rp } \\
70,000\end{array}$ \\
\hline 3. & Electrode & $2 \mathrm{~mm}$ & $\begin{array}{c}\text { IDR } \\
70,000\end{array}$ & $1 / 2$ & $\begin{array}{c}\text { IDR } \\
35,000\end{array}$ \\
\hline 4. & $\begin{array}{l}\text { Zinc } \\
\text { Chromate }\end{array}$ & & $\begin{array}{c}\text { IDR } \\
33.000\end{array}$ & $1 / 2$ & $\begin{array}{c}\text { IDR } \\
16,500\end{array}$ \\
\hline 5. & Putty & & $\begin{array}{c}\text { IDR } \\
13,000\end{array}$ & $250 \mathrm{gr}$ & $\begin{array}{c}\text { IDR } \\
13,000\end{array}$ \\
\hline 6. & Paint & & $\begin{array}{c}\text { IDR } \\
54,000\end{array}$ & $3 / 4$ & $\begin{array}{c}\text { IDR } \\
40,500\end{array}$ \\
\hline 7. & $\begin{array}{l}\text { Welding } \\
\text { Wire }\end{array}$ & & $\begin{array}{c}\text { IDR } \\
7,500\end{array}$ & $1 \mathrm{~kg}$ & $\begin{array}{c}\text { IDR } \\
7,500\end{array}$ \\
\hline 8. & $\begin{array}{l}\text { Nuts and } \\
\text { bolts }\end{array}$ & & $\begin{array}{c}\text { IDR } \\
5,000\end{array}$ & 12 & $\begin{array}{c}\text { IDR } \\
60,000\end{array}$ \\
\hline
\end{tabular}

At this development stage, an alternative cost analysis is used to determine the price of the product in each making 1 unit of each alternative available in Table 6 , Table 7 , and Table 8.

Table 7: Calculation of alternative II

\begin{tabular}{|c|l|c|c|c|c|}
\hline No & Material & Diameter & $\begin{array}{c}\text { Unit } \\
\text { Price }\end{array}$ & Amount & Total \\
\hline 1. & $\begin{array}{l}\text { Hollow } \\
\text { Iron 3x3 }\end{array}$ & $1.2 \mathrm{~mm}$ & $\begin{array}{c}\text { IDR } \\
66,000\end{array}$ & 2 & $\begin{array}{c}\text { IDR } \\
132,000\end{array}$ \\
\hline 2. & $\begin{array}{l}\text { Hollow } \\
\text { Iron 2x2 }\end{array}$ & $1 \mathrm{~mm}$ & $\begin{array}{c}\text { IDR } \\
62,000\end{array}$ & 1 & $\begin{array}{c}\text { IDR } \\
62,000\end{array}$ \\
\hline 3. & $\begin{array}{l}\text { Wooden } \\
\text { Planks }\end{array}$ & & $\begin{array}{c}\text { IDR } \\
70,000\end{array}$ & $1 / 2$ & $\begin{array}{c}\text { IDR } \\
35,000\end{array}$ \\
\hline 4. & Bracket & & $\begin{array}{c}\text { IDR } \\
27,500\end{array}$ & 2 & $\begin{array}{c}\text { IDR } \\
55,000\end{array}$ \\
\hline 5. & $\begin{array}{l}\text { Sponge } \\
1 x 1\end{array}$ & & $\begin{array}{c}\text { IDR } \\
17,500\end{array}$ & 1 & $\begin{array}{c}\text { IDR } \\
17,500\end{array}$ \\
\hline 6. & Zinc & & $\begin{array}{c}\text { IDR } \\
33,000\end{array}$ & $1 / 2$ & $\begin{array}{c}\text { IDR } \\
16,500\end{array}$ \\
\hline 7. & Putty & & $\begin{array}{c}\text { IDR } \\
13,000\end{array}$ & 1 & $\begin{array}{c}\text { IDR } \\
13,000\end{array}$ \\
\hline 8. & Paint & & $\begin{array}{c}\text { IDR } \\
54,000\end{array}$ & $1 / 2$ & $\begin{array}{c}\text { IDR } \\
27,000\end{array}$ \\
\hline 9. & Electrode & 2 mm & $\begin{array}{c}\text { IDR } \\
70,000\end{array}$ & $1 / 4$ & $\begin{array}{c}\text { IDR } \\
17,500\end{array}$ \\
\hline 10 & Welding & & $\begin{array}{c}\text { IDR } \\
7,500\end{array}$ & $1 \mathrm{~kg}$ & $\begin{array}{c}\text { IDR } \\
7,500\end{array}$ \\
\hline 11 & Wire & Screw \\
bolts & & $\begin{array}{c}\text { IDR } \\
11,500\end{array}$ & $1 / 4$ & $\begin{array}{c}\text { IDR } \\
2,875\end{array}$ \\
\hline 12 & Hinge & & $\begin{array}{c}\text { IDR } \\
5,000\end{array}$ & 14 & $\begin{array}{c}\text { IDR } \\
70,000\end{array}$ \\
\hline & & & $\begin{array}{c}\text { IDR } \\
455,875\end{array}$ \\
\hline
\end{tabular}

Table 8: Calculation of alternative III

\begin{tabular}{|c|c|c|c|c|c|}
\hline No & Material & Diameter & $\begin{array}{l}\text { Unit } \\
\text { Price }\end{array}$ & Amount & Total \\
\hline 1. & $\begin{array}{l}\text { Hollow } \\
\text { Iron } 3 \times 3\end{array}$ & $1.2 \mathrm{~mm}$ & $\begin{array}{c}\text { IDR } \\
66,000\end{array}$ & $21 / 2$ & $\begin{array}{c}\text { IDR } \\
165,000\end{array}$ \\
\hline 2. & $\begin{array}{l}\text { Hollow } \\
\text { Iron } 2 \times 2\end{array}$ & $1 \mathrm{~mm}$ & $\begin{array}{c}\text { IDR } \\
62,000\end{array}$ & $1 \frac{1 / 2}{2}$ & $\begin{array}{c}\text { IDR } \\
93,000\end{array}$ \\
\hline 3. & Lock & & $\begin{array}{c}\text { IDR } \\
20,000\end{array}$ & 4 & $\begin{array}{c}\text { IDR } \\
80,000\end{array}$ \\
\hline 4. & $\begin{array}{l}\text { Wooden } \\
\text { Planks }\end{array}$ & & $\begin{array}{c}\text { IDR } \\
70,000\end{array}$ & 1 & $\begin{array}{c}\text { IDR } \\
70,000\end{array}$ \\
\hline 5. & Sponge & & $\begin{array}{c}\text { IDR } \\
17,500\end{array}$ & 1 & $\begin{array}{c}\text { IDR } \\
17,500\end{array}$ \\
\hline 6. & $\begin{array}{l}\text { Zinc } \\
\text { Chromate }\end{array}$ & & $\begin{array}{c}\text { IDR } \\
33,000 \\
\end{array}$ & $1 / 2$ & $\begin{array}{c}\text { IDR } \\
16,500\end{array}$ \\
\hline 7. & Putty & & $\begin{array}{c}\text { IDR } \\
13,000\end{array}$ & $250 \mathrm{gr}$ & $\begin{array}{c}\text { IDR } \\
13,000\end{array}$ \\
\hline 8. & Paint & & $\begin{array}{c}\text { IDR } \\
54,000\end{array}$ & $1 / 2$ & $\begin{array}{c}\text { IDR } \\
27,000\end{array}$ \\
\hline 9. & Electrode & $2 \mathrm{~mm}$ & $\begin{array}{c}\text { IDR } \\
70,000\end{array}$ & $1 / 2$ & $\begin{array}{c}\text { IDR } \\
35,000\end{array}$ \\
\hline 10 & $\begin{array}{l}\text { Welding } \\
\text { Wire }\end{array}$ & & $\begin{array}{c}\text { IDR } \\
7,500\end{array}$ & $1 \mathrm{~kg}$ & $\begin{array}{c}\text { IDR } \\
7,500\end{array}$ \\
\hline 11 & $\begin{array}{l}\text { Screw } \\
\text { bolts }\end{array}$ & & $\begin{array}{c}\text { IDR } \\
11,500\end{array}$ & $1 / 4$ & $\begin{array}{c}\text { IDR } \\
2,875\end{array}$ \\
\hline \multicolumn{5}{|c|}{ Total } & $\begin{array}{c}\text { IDR } \\
527,375\end{array}$ \\
\hline
\end{tabular}


After calculating the cost analysis of the product manufacture each alternative further determines the ratio value of Value Engineering. A product or service can be said to be good if the product has good performance and accordingly. Cooper [10] said that value is an approach that uses consumers as its orientation. In other words, it is a consumer approach that uses products to get the value of the performance as expected. The last stage in the value engineering is determining the measured value of the performance score divided by the basic cost of the product in each alternative. So the result can be seen in Table 9.

Table 9: Price of the product calculation result

\begin{tabular}{|l|c|c|c|c|}
\hline Alternative & $\begin{array}{c}\text { Price of the } \\
\text { product }\end{array}$ & $\begin{array}{c}\text { Performan } \\
\text { ce Score }\end{array}$ & Value & $\begin{array}{c}\text { Ranki } \\
\text { ng }\end{array}$ \\
\hline $\begin{array}{l}\text { Alternative } \\
\text { I }\end{array}$ & $\begin{array}{c}\text { IDR } \\
473,500\end{array}$ & 2727 & 0.00576 & 2 \\
\hline $\begin{array}{l}\text { Alternative } \\
\text { II }\end{array}$ & $\begin{array}{c}\text { IDR } \\
455,875\end{array}$ & 2724 & 0.00598 & 1 \\
\hline $\begin{array}{l}\text { Alternative } \\
\text { III }\end{array}$ & $\begin{array}{c}\text { IDR } \\
527,375\end{array}$ & 2762 & 0.00523 & 3 \\
\hline
\end{tabular}

The images below (Figure 6 to Figure 9) show the development of an alternative II that can change based on the functionality.



Figure 6: Design I

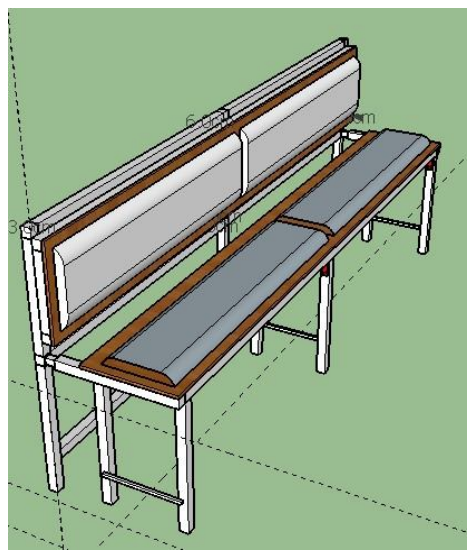

Figure 7: Design II



Figure 8: Design III



Figure 9: Design IV

\section{CONCLUSION}

The integration of QFD and Value Engineering in this study seeks to produce products that fit the needs of customers and reduce the cost of manufactured products but does not eliminate the functions that exist in previous products. The conclusion from this research is there is three alternative designs for waiting chair product. The otal of product performance from each alternative is 2727, 2724, and 2762. The cost from each alternative is alternative 1 IDR 473.500, alternative II IDR 455.875, and alternative III IDR 527.375. The results showed that increasing the development of waiting chair products in this case could reduce product manufacturing costs by Rp. 90.625. The weakness from this research is the product still in prototype design.

\section{ACKNOWLEDGEMENT}

Thanks to Kadiri University for the 2019 research funding.

\section{REFERENCES}

1. L. I. Batan. Desain Produk, Edisi Pertama, "Desain Produk", Guna Widya, Surabaya (1st ed.), 2012.

2. S. D. Eppinger, and K. T. Ulrich. Product design and development, Singapore: McGraw, 1995.

3. Y. Akao, B. King, and G. H. Mazur. Quality function deployment: integrating customer requirements into product design (Vol. 21). Productivity press Cambridge, MA, 1990.

4. J. Y. Farsi, and N. Hakiminezhad. The integration of QFD technique, value engineering and design for manufacture and assembly (DFMA) during the 
product design stage, Advances in Environmental Biology, pp. 2096-2105, 2012.

5. L. K. Chan, and M. L. Wu. Quality function deployment: A literature review, European Journal of Operational Research, vol. 143, no. 3, pp. 463-497, 2002.

6. V. Nanda. Quality management system handbook for product development companies, CRC press, 2016.

7. R. Park. Value Engineering. A Plan for Invention, New York, St. Lucie Press, 1999.

8. K. A. A. Ahmed, and R. K. Pandey. Concept of value engineering in construction industry, International Journal of Science and Research (IJSR), ISSN, pp. 2319-7064, 2016.

9. A. M. Benur, and B. Bramwell. Tourism product development and product diversification in destinations, Tourism Management, vol. 50, pp. 213-224, 2015.

10. R. G. Cooper. Agile-Stage-Gate Hybrids: The Next Stage for Product Development Blending Agile and Stage-Gate methods can provide flexibility, speed, and improved communication in new-product development, Research-Technology Management, vol. 59, no. 1, pp. 21-29, 2016.

11. G. Anand, and R. Kodali. Development of a conceptual framework for lean new product development process, International Journal of Product Development, vol. 6, no. 2, pp. 190-224, 2008.

12. J. Gao, and A. Bernard. An overview of knowledge sharing in new product development, The International Journal of Advanced Manufacturing Technology, vol. 94, no. 5-8, pp. 1545-1550, 2018.

13. Z. Yuan, C. Sun, and Y. Wang. Design for Manufacture and Assembly-oriented parametric design of prefabricated buildings, Automation in Construction, vol. 88, pp. 13-22, 2018.

14. C. Boks, and T. C. McAloone. Transitions in sustainable product design research, International Journal of Product Development, vol. 9, no. 4, pp. 429-449, 2009.
15. H. Min, J. Yun, and Y. Geum. Analyzing dynamic change in customer requirements: An approach using review-based Kano analysis, Sustainability, vol. 10, no. 3, p. 746, 2018.

16. J. A. Harding, K. Popplewell, R. Y. K. Fung, and A. R. Omar. An intelligent information framework relating customer requirements and product characteristics, Computers in Industry, vol. 44, no. 1, pp. 51-65, 2001,

17. M. Bertoni, A. Bertoni, and O. Isaksson. Evoke: A value-driven concept selection method for early system design, Journal of Systems Science and Systems Engineering, vol. 27, no. 1, pp. 46-77, 2018.

18. B. López-Mesa, and N. Bylund. A study of the use of concept selection methods from inside a company, Research in Engineering Design, vol. 22, no. 1, pp. 7-27, 2011. https://doi.org/10.1007/s00163-010-0093-2

19. K. C. Tan, and T. A. Pawitra. Integrating SERVQUAL and Kano's model into QFD for service excellence development, Managing Service Quality: An International Journal, vol. 11, no. 6, pp. 418-430, 2001.

20. H. Camgöz-Akdağ, M. Tarım, S. Lonial, and A. Yatkın. QFD application using SERVQUAL for private hospitals: a case study, Leadership in Health Services, vol. 26, no. 3, pp. 175-183, 2013.

21. R. John, A. Smith, S. Chotipanich, and M. Pitt. Awareness and effectiveness of quality function deployment (QFD) in design and build projects in Nigeria, Journal of Facilities Management, vol. 12, no. 1, pp. 72-88, 2014.

22. Saaideh, M.A., Ananbeh, O., Almomani, T., Feilat, E.A., Khasawneh, H.J. Power quality audit of a school of engineering building - case study, International Journal of Emerging Trends in Engineering Research 8(1), pp. 151-156, 2020 https://doi.org/10.30534/ijeter/2020/20812020

23. Kim, W.L., Lim, S.B. Smart chair cover for posture correction, International Journal of Emerging Trends in Engineering Research 7(8), pp. 191-196, 2019 https://doi.org/10.30534/ijeter/2019/14782019 